Caso para Ensino Convidado

\title{
Desafios da Pandemia para o Futuro da Educação: O Caso Coppead
}

\author{
Challenges for the Future of Education brought by the Pandemic: The \\ Coppead Case
}

\section{INTRODUÇÃO}

Eram 10h da manhã de 17 de março de 2020, e Elaine Tavares, diretora do Coppead, a Escola de Negócios da Universidade Federal do Rio de Janeiro (UFRJ), estava apreensiva. Em poucos minutos ela daria início à reuniáo do Conselho Deliberativo (CD) do Coppead, com participação de todo o corpo docente e representantes dos alunos e colaboradores. Tratava-se de um CD extraordinário, que a própria Elaine havia convocado, no qual ela precisava convencer os professores a migrarem seus cursos para um ambiente virtual com urgência. Sua apreensão era justificada, pois, no passado, o Coppead havia tentado, sem sucesso, convencer os mesmos docentes a aderirem a modelos digitais de ensino. Todos entendiam que era preciso planejamento para isso. Essa mudança precisaria se dar por convencimento da maioria, uma vez que a escola tem suas principais decisóes baseadas no modelo colegiado.

O novo impulso para a migração imediata para o formato on-line era a quarentena provocada pela disseminação do COVID-19, uma pandemia sem precedentes na era moderna que estava obrigando todos a alterarem radicalmente suas rotinas em prol do isolamento social. Com alunos e professores isolados em casa, aderir a aulas remotas seria a única alternativa para não paralisar as atividades de ensino da escola.

Elaine começou a reunião on-line declarando que a quarentena provocada pelo COVID-19 trazia um sentido de urgência para a instituiçáo, que precisava decidir rapidamente se daria aulas on-line naquele período. Imediatamente um professor pediu a palavra e declarou que era preciso se mover rapidamente nessa direção, a fim de não parar os cursos de mestrado, doutorado e pós-graduação lato sensu em andamento. Pelas expressóes dos docentes e cabeças acenando em concordância, Elaine percebeu que alguma coisa fundamental havia mudado e que sua tarefa seria mais fácil do que ela antecipara. 


\section{INOVAÇÃO NO DNA}

O Coppead foi criado em 1973, com recursos da Finep. Quatro professores da Coppe ${ }^{1}$, Ney Brito, Paulo Fleury, Marcos Villela e Moises Swirski, aceitaram o desafio e criaram um mestrado em administração com base nos melhores MBAs do mundo. Era um programa muito pequeno e havia uma dificuldade enorme para contratar docentes e atrair alunos. Os 12 alunos da primeira turma foram recrutados na Coppe. Essa primeira turma teve sete professores. Alguns alunos que se formavam eram contratados como docentes e o programa também recebia muitos professores visitantes e conferencistas. Os professores do Coppead começaram a divulgar o programa pelo Brasil e a segunda turma teve 50 alunos.

O Prof. Paulo Lemos, recém-chegado no Coppead, foi a Brasília explicar para a Capes a importância de um mestrado em administração voltado para o mercado. Até então só se falava em formar acadêmicos, mas nas escolas norte-americanas ele conheceu o full-time MBA, um programa de tempo integral visando à sólida formação de alunos que objetivam voltar ao mercado, e reconheceu a importância desse modelo na pós-graduação em administração, uma ciência social aplicada. Esse é desde então o DNA do Coppead. Uma escola inovadora, que oferta uma sólida formação acadêmica, orientada para a prática.

Em 1976, o Prof. Paulo Lemos foi aos EUA conhecer o MBA Executivo, que estava sendo lançado naquele país. $\mathrm{Na}$ sua volta, propôs a criação do curso, porque percebia que o programa precisava ter recursos próprios. A ideia foi maturada até 1982, quando o Coppead lançou o primeiro MBA Executivo do Brasil.

Em 1980, o Coppead criou a Central Brasileira de Casos e o método do caso passou a estruturar o ensino do Coppead. Isso foi fruto do treinamento dado por professores canadenses, que vieram ao Brasil disseminar o método anos antes, e das discussóes que os fundadores do Coppead tiveram nos Estados Unidos sobre métodos de ensino. Nesse mesmo ano, foi instituído o programa de doutorado da escola.

Em 1984, o Coppead criou o programa de cátedras - voltado para a relação universidade-empresa - que trata do financiamento privado das pesquisas da escola. Além de aportar recursos para a investigação, o modelo dá à escola oportunidade de estabelecer agenda de pesquisa relevante para o mercado e abre as portas das empresas para pesquisa. A escola conta com as cátedras como uma importante fonte de financiamento e possui em 2020 dez cátedras vigentes.

A história do Coppead é marcada pela inovação desde sua fundaçáo. A escola foi uma das primeiras a estabelecer um forte programa de intercâmbio com escolas internacionais, colocou em 2002 seu mestrado no ranking do Financial Times e, desde então, listou o curso ali diversas vezes; no início dos anos 2000, já tinha um conselho consultivo empresarial. Em 2015, a escola passou a ter um mestrado integralmente em inglês, com alunos regulares estrangeiros, pois ao longo do tempo a instituição também construiu uma estratégia de internacionalização.

Apesar de se manter inovando ao longo dos anos, alguns professores do Coppead se perguntavam recentemente se o ritmo de inovação estava adequado. A preocupação em manter a excelência parecia deixar a escola com medo de errar e a toda inovaçáo tinham que se provar relevantes para substituir produtos reconhecidos como de sucesso na história da instituição.

A escola tinha uma breve experiência com ensino mediado por tecnologia, mas havia uma crença de que existiam barreiras consideráveis para desenvolvêlo adequadamente, mantendo o método de ensino e aprendizagem focado no aluno, algo que faz parte da filosofia de ensino e da identidade da escola. $\mathrm{O}$ entendimento dos professores da escola é de que o aluno tem que ser protagonista da sua aprendizagem, que vem da totalidade dos integrantes da sala de aula e não só do professor. A escola sempre se baseou num processo seletivo rigoroso, em todos os seus cursos, para garantir composiçóes de turma onde os alunos também tivessem uma forte contribuição para o grupo.

Em 2019, foi iniciada na instituição uma ampla pesquisa para amparar novas frentes estratégicas. Havia o sentimento de que a sala de aula deveria incorporar dimensóes mais digitais para atender às demandas do ensino para executivos. No entanto, ainda não era claro como isso poderia se articular a uma pedagogia centrada no aluno, em torno do debate e da interação, principal marca da instituição.

Como trazer esse protagonismo do aluno para o ambiente virtual? $\mathrm{O}$ caminho deveria passar por meios síncronos de aprendizagem, em que o professor pudesse interagir com a turma em tempo real, desafiando os alunos. E o networking da turma, outro ponto minuciosamente construído na escola, como ficaria? Era preciso cautela para navegar por esses mares. Era preciso estudar plataformas de EAD síncrono, adquirir um ferramental tecnológico robusto e estruturar um projeto consistente, que garantisse que os professores da escola continuassem se orgulhando ao sair de cada aula. 


\section{TECNOLOGIA E NOVOS MOVIMENTOS EM EDUCAÇÃO}

As inovaçóes no campo de educação vinham ampliando o ecossistema para muito além dos atores mais tradicionais: escola, editoras, alunos, professores e empresas. De forma geral, as plataformas digitais se tornaram um vetor potencializador da iniciativa de diversos novos participantes que ampliam, reinventam ou criam novos produtos de conteúdo e educação. Esse movimento possibilitou também a diversificação do perfil daqueles que passaram a atuar em educação executiva.

A partir de 2012, escolas internacionais tradicionais como Columbia, MIT e Harvard passaram a oferecer cursos de curta duração, em plataformas on-line, anunciados em mídias sociais para o público brasileiro. Mesmo os tradicionais MBAs, cujo declínio é alardeado há décadas na imprensa especializada, passaram a ser desenhados em modelos híbridos (presencial e on-line), percorrendo diversos países e combinando semanas assíncronas e digitais com encontros presenciais e intensivos. No mercado brasileiro, os cursos on-line trazem parcerias entre diversas instituiçóes, como parcerias acadêmico-empresariais ou internacionais, como o curso Renovação Digital oferecido pela Escola de Negócios Saint Paul em parceria com a IBM ou o portfólio de cursos on-line da PUC-RS, em conjunto com personalidades de destaque no cenário empresarial brasileiro e internacional. No mercado brasileiro, grandes instituiçôes de ensino, como a Universidade Estácio de Sá, têm atuado na oferta de cursos em EAD, provendo formaçáo barata e acessível a um grande número de alunos em todo o país.

Outro movimento emergente a partir de 2012 foram os MOOCs (Massive Open Online Courses), como Coursera, EDX, Udemy, Future Learn, Udacity, entre outros. Nessas plataformas, alunos em qualquer parte do mundo podem ter acesso a conteúdos diversos, de forma simples e muitas vezes mais barata. Muitas dessas plataformas foram criadas por instituiçóes tradicionais que enxergaram nesse canal uma nova oportunidade de acesso aos alunos. A Edx², por exemplo, foi criada pela Universidade de Harvard e pelo MIT como uma iniciativa sem fins lucrativos, com uma oferta gratuita de cursos, e pagamento para emissão de certificados. A Emeritus foi fundada por MIT, Columbia e Tuck/Dartmouth e se concentrou no cenário de negócios, com oferta de cursos diferenciados e mais caros. A Udemy, por outro lado, segue uma lógica de marketplace, abrigando uma oferta ampla e diversificada, com mais de 100.000 cursos disponíveis para contratação por preços acessíveis. A essas iniciativas se somam exemplos nacionais como a plataforma LIT da Saint Paul, construída sobre uma engenhosa plataforma de inteligência artificial, com pílulas de aprendizado em conteúdo digital.
Todas essas iniciativas funcionam dentro da lógica de microcertificaçôes, que vão oferecendo diplomas a cada pequena conquista, materializando no currículo do aluno seu progresso de aprendizado, como é o caso do programa MicroMasters da Edx, apoiado por diversas empresas. Atores como Google, HubSpot e YouTube também passaram a oferecer diversos cursos com certificação, energizando o segmento. As diversas iniciativas emergentes de certificações criaram paulatinamente uma nova regra do jogo para os currículos em diversas áreas, como marketing e finanças.

Novos atores que não têm origem no segmento educacional tradicional também se aventuraram a oferecer soluçôes de ensino alternativas. As chamadas Edtechs recriaram formatos e reinventaram a narrativa da educação executiva. Algumas, como a Be Academy ${ }^{3}$, advogavam as desvantagens de ambientes acadêmicos, e convidavam profissionais de mercado para conduzirem o aprendizado de seus alunos. Essa oferta é marcada pela cultura de startups e aceleradoras, estimulando formatos curtos, hands-on e intensivos, como os bootcamps da Tera ${ }^{4}$. A promessa dessas ofertas está na quebra de paradigmas não só empresariais, mas também educacionais, reinventando a forma de aprender.

As consultorias também passaram a investir em um braço de treinamento, em exemplos como a McKinsey Academy ou programas da Accenture. Por fim, editoras, como a HSM Management ${ }^{5}$, aventuram-se no setor, com ofertas de cursos em diversos formatos. O setor assistiu ainda a entrada de novos atores como o Descomplica, uma plataforma de ensino integralmente digital para o ensino médio, que com o sucesso de seu modelo orquestrou sua expansão para o ensino superior.

Além disso, muitos profissionais não provenientes de instituiçóes de ensino passaram a se tornar importantes vozes e provedores de conteúdo em áreas como branding, liderança e consumo, pilotando canais de YouTube, tornando-se Top Voices do LinkedIn ou lançando seus próprios podcasts. Muitos executivos passaram a recorrer a apps como Audible, para escutar livros enquanto faziam esporte ou dirigiam para o trabalho. Esses formatos passaram a ser percebidos por parte dos executivos como potencialmente mais fáceis de serem encaixados na dinâmica de suas vidas e como facilitadores do aprendizado na vida adulta, pelo processo de microlearning.

Escolas tradicionais como Harvard já experimentavam, há muitos anos, modelos on-line amparados em uma sofisticada estrutura tecnológica. Como noticiado em 2015 pela Fox Business, a Harvard Business School ofertou uma versão alternativa à sua tradicional sala de aula, baseada em discussóes de caso em um estúdio de TV, promovendo a interação de alunos em todas as partes do globo. 


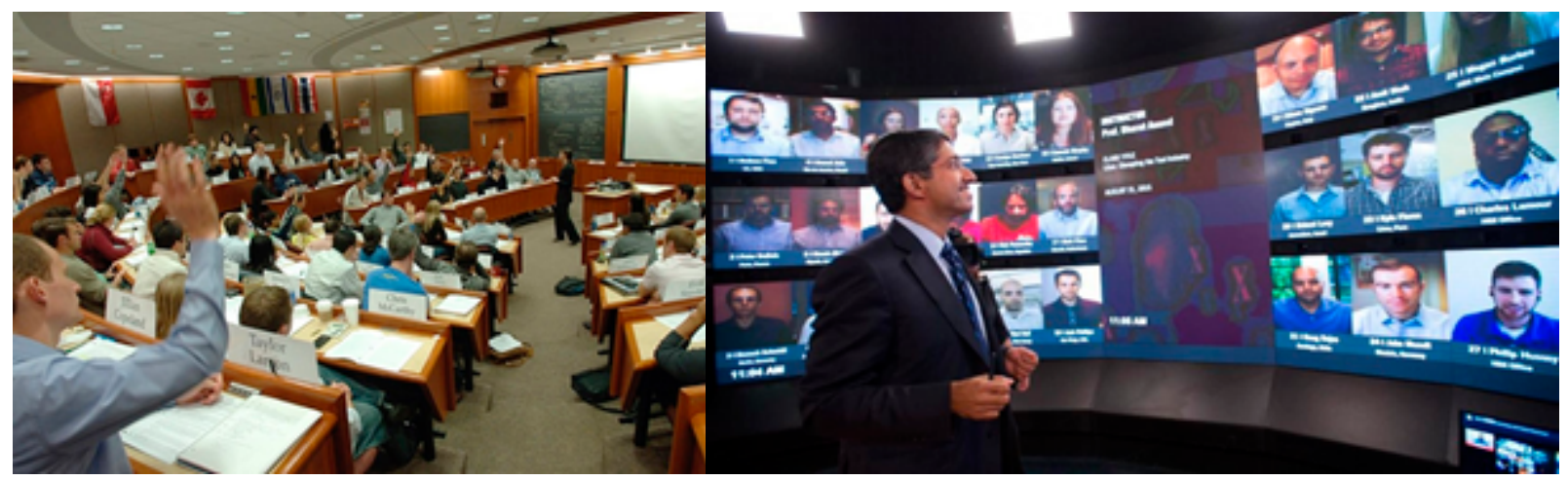

Figura 1. A aula de Harvard de método do caso em uma sala tradicional e uma sala on-line.

Fonte: Adaptado de Yang, G. (2019). Is it time to retire the Harvard Case Study? Retrieved from https://poetsandquants.com/2019/10/05/is-it-timeto-retire-the-harvard-case-study/ e At Harvard's new 'virtual classroom,' students tune in to class from computers anywhere. (2015). Fox Business. Retrieved from https://www.foxbusiness.com/features/at-harvards-new-virtual-classroom-students-tune-in-to-class-from-computers-anywhere

O exemplo de Harvard era ainda uma exceção. Poucos eram os players que usavam o digital para oferecer uma sala de aula síncrona e centrada no debate e na troca, favorecendo o desenvolvimento de competências comportamentais e emocionais (as chamadas soft skills), além da transmissão de conceitos. Esse movimento era praticamente inexistente no mercado brasileiro, que parecia mais familiarizado com o $\mathrm{EAD}$ em formatos assíncronos.

Em paralelo à digitalização, outro movimento na educação executiva é a oferta de programas presenciais de imersão e formatos alternativos à sala de aula voltados para o desenvolvimento de soft skills. Normalmente são programas síncronos e presenciais, baseados na construção de sólido network e em experiências únicas. Players como Amana-Key oferecem programas de três a cinco dias, com uma imersão e distanciamento da rotina dos participantes, e favorecidos por experiências lúdicas e muito diferentes do padráo de ensino presente em salas de aula de instituiçóes de ensino tradicionais. A Hyper Island é outro exemplo dessa oferta alternativa. Trata-se de uma escola internacional com sede em países como Brasil, Finlândia, Singapura, Suécia, Inglaterra e Estados Unidos. Oferece cursos de diversas duraçôes, mas sempre com uma sala de aula atípica, de natureza aplicada e customizada, e centrada em projetos reais e transversais. Outros players tradicionais também se aventuraram nesse segmento, oferecendo produtos com formatos diferenciados, que combinam sessóes individuais de coach com sessōes online e encontros presenciais.

Com a pandemia, muitas instituições de ensino internacionais anunciaram a ampliação de seu portfólio online ou mesmo de programas híbridos, apontando para a ampliaçáo do digital na oferta de conteúdos relevantes para os diversos segmentos de mercado. Os cursos $100 \%$ online ou em EAD eram vistos como potentes mecanismos de inclusão e de formação em massa, muito relevantes em países emergentes, que ainda apresentavam uma grande lacuna de oferta e de formaçáo de força de trabalho. Por outro lado, começou uma discussão sobre o valor da experiência presencial, pois, com a experimentaçáo do consumo digital forçado pela pandemia, muitos potenciais alunos começaram a questionar o real valor dos caríssimos cursos presenciais, em campi distantes e luxuosos das grandes e prestigiosas escolas de negócios do mundo. Mesmo após a pandemia, o retorno ao presencial poderá ser acompanhado por uma reinvenção do encontro da sala de aula.

\section{EXPERIÊNCIAS ANTERIORES NO EAD}

O Coppead começou suas incursôes pelo EAD em 2010. Na ocasiáo, a escola ofertou um curso de MBA em EAD para o Banco do Brasil. Também produziu gravaçóes de vídeo para conteúdos de nivelamento do MBA Executivo. Entretanto, os professores percebiam que as plataformas de ensino assíncronas eram interessantes para disseminar alguns conteúdos, mas não reproduziam o ambiente de sala de aula pelo qual o Coppead sempre zelou. Em relação a sistemas de apoio on-line (learning management systems), o Coppead usa há alguns anos a plataforma AVA para disponibilização do material, mas nem todos os docentes utilizam a plataforma para interaçáo com os alunos.

Em resumo, o EAD assíncrono até poderia ser complementar, mas não se mostrou uma soluçáo estruturante para a digitalização dos cursos da escola, pela perda do processo de ensino e aprendizagem focado no aluno e também pelo tempo de produção dos conteúdos. Por ser uma escola pequena, o ritmo de produçáo de material seria inadequado e tomaria um tempo enorme dos professores, prejudicando outras atividades, como a pesquisa, fundamental para trazer conteúdo inovador para a sala de aula. $\mathrm{O}$ EAD assíncrono, em ampla escala, afastaria a escola de suas competências. Já 
o EAD síncrono parecia ser um caminho por possibilitar o foco no aluno e prover uma alternativa mais próxima da essência de sala de aula do Coppead, mas ainda não havia conquistado muitos adeptos entre os docentes. Em 2019, a escola se engajou em um grande projeto de revisão da sua estratégia e de pesquisa dos novos métodos de ensino e das necessidades do público executivo. Os aprendizados desse intenso ano de estudo levariam ao desenho de novos produtos. Só que "a vida é o que acontece enquanto a gente planeja”.

\section{CHEGA A PANDEMIA}

$\mathrm{Na}$ sexta-feira, 13 de março, Elaine estava numa reunião em sua sala, quando chegou pelo WhatsApp a notícia de que a universidade estava suspendendo suas atividades por conta da pandemia, seguindo um decreto estadual. A reuniáo se encerrou naquele momento e Elaine acionou todos os coordenadores de curso, para que cancelassem as próximas aulas até que a escola deliberasse sobre seu funcionamento.

Elaine já havia convocado uma reunião com todos os docentes para a terça-feira seguinte, para discutir as ações para a pandemia, pois desde o dia 11 percebia a possibilidade de fechamento. Mas uma preocupaçáo não saía de sua cabeça: os professores da escola, sempre muito zelosos pela marca e pela qualidade do ensino, aceitariam migrar as aulas para o ambiente virtual? Ela acreditava numa resistência muito grande. E se não aceitassem? Por quanto tempo o Coppead permaneceria sem aula? $\mathrm{O}$ quanto isso iria comprometer a formação dos alunos? Como ficaria a reputação da escola?

Ela chegou à reunião de terça-feira com a preocupação que só crescera no final de semana. No sábado, ela adquiriu uma licença do Zoom e a própria reunião já ganhou novo formato, pois parte dos docentes já manifestara que não poderia ir à escola, por integrar grupo de risco. Fazer uma reunião táo importante por um meio ainda novo também poderia ser complicado. Elaine começou a reunião com um discurso acalorado sobre por que era essencial a virtualização das aulas de forma síncrona naquele momento. O Coppead não podia parar.

Não deveria haver problemas para a continuidade da pesquisa, mas para o ensino a situação era potencialmente catastrófica. $\mathrm{O}$ ano tinha acabado de começar. A maioria das turmas tinha pisado pela primeira vez em sala de aula há cerca de um mês. Conheciam-se pouco, mas estavam animados com o curso e com a integração com seus novos colegas. Parar para voltar quando? Para os alunos, seria a interrupçáo de um projeto pessoal muito importante. No mestrado, muitos tinham pedido demissão para se dedicarem ao estudo. Deixar de formar quadros numa situação tão crítica para o país seria negligenciar a missão da escola. Seria um ano perdido para o Coppead. A evasão escolar em todos os cursos seria claramente aumentada, um problema que a escola nunca enfrentara. A suspensão dos contratos seria também causa de demissóes dos funcionários contratados pela CLT, o que desestruturaria a escola pelos próximos anos, pois o conhecimento dos processos seria perdido. E por quanto tempo as crises sanitária e econômica iriam perdurar? As outras escolas certamente adotariam uma trajetória virtual. O cenário era avassalador e Elaine nunca estivera tão preocupada com os rumos da escola.

Os professores da escola surpreenderam. A relevância da escola sempre foi algo que motivou o grupo. Todos entenderam prontamente que, para se manter relevante, a adoção do ensino síncrono precisava acontecer com urgência. $\mathrm{O}$ clima era de confiança na qualidade do corpo docente e o entendimento era de que, mesmo sem o tão almejado planejamento, tudo daria certo, pois a motivação era enorme.

Enquanto a congregação da escola deliberava pelo ensino remoto, chegou uma notícia de que a modalidade não seria aceita na UFRJ. Elaine deixou a reuniáo e consultou uma autoridade da universidade, que apontou que naquele mesmo dia o Ministério da Educação emitiu portaria permitindo a virtualização das aulas na pandemia. A universidade deveria permitir que as aulas fossem virtualizadas para cursos que já tivessem EAD. A escola se ateve ao fato de já usar o AVA em todos os cursos, o que implicava a necessidade de os alunos terem recursos tecnológicos para acompanhar suas aulas. Não havia tempo para esperar esse cenário clarear.

O passo seguinte foi a união do corpo docente em torno da escolha da plataforma e do treinamento de todos para que as aulas pudessem ser ministradas no novo ambiente. O Zoom, além de ter um custo factível, mostrouse incrivelmente parecido com as possibilidades da sala de aula do Coppead. As turmas poderiam ser divididas em grupos pequenos para discussão dos casos, como ocorre na escola em salas de reunião que ficam ao lado dos centros de treinamento; os alunos poderiam levantar a máo para organizar a discussão, e era possível compartilhar tela e realizar enquetes. $\mathrm{O}$ desafio de encontrar uma solução tecnológica que acomodasse as competências da escola, que antes parecera enorme, fora rapidamente vencido. Não era preciso ter uma infraestrutura tecnológica sofisticada, porque já havia solução pronta para o básico, o processo de comunicação. A impressão original de que isso demandaria um alto investimento, como no caso de Harvard, foi vencida pela comoditização da tecnologia. Essa descoberta de que a tecnologia era acessível ajudou a apaziguar as inseguranças do grupo.

Eleita a plataforma tecnológica, era hora de treinar a equipe para usá-la. Os professores mais familiarizados com a tecnologia assumiram a liderança desse processo e 
uma série de reunióes ocorreu entre docentes e convidados para conhecerem a ferramenta e darem aulas experimentais para os colegas. A equipe da secretaria acadêmica também foi treinada, pois tal como ocorre nas aulas do Coppead, uma secretária e um técnico de TI precisam estar sempre disponíveis e, nesse caso, estariam na sala virtual com o professor, para socorrer docentes e alunos em dificuldades técnicas.

A escola, que seguia um tech code que não permitia o uso de tecnologia em sala de aula para não gerar dispersão, precisava repensar suas regras. Foi preciso orientar os alunos e toda a equipe sobre como se comportar nesse ambiente virtual e como melhor dispor da tecnologia para o ensino e aprendizagem. Além de diversas reunióes via Zoom, grupos de discussão no WhatsApp auxiliaram nesse processo, sendo também criados para suporte tecnológico aos alunos.

No dia 23 de março, poucos dias depois da decisão da virtualização das aulas, a escola já estava preparada para o retorno no novo ambiente. As aulas recomeçaram e junto com elas o compartilhamento das experiências entre colegas e as celebraçóes a cada caso de sucesso. A insegurança com um meio ainda novo perdia espaço para o orgulho de pertencimento a um time engajado de profissionais.

No mestrado e no doutorado, o retorno aconteceu com muita naturalidade $\mathrm{e}$ as aulas foram muito bemsucedidas. $\mathrm{Na}$ educação executiva, o desafio foi maior. $\mathrm{O}$ comunicado inicial de que as aulas seriam retomadas no mesmo formato das aulas anteriores causou preocupação nos alunos. Oito horas de encontro, tal como ocorre na sala de aula física, era um exagero para o ambiente virtual em tempo de pandemia. $\mathrm{Na}$ ânsia de ofertar uma solução com brevidade, a escola não conversou com os alunos. Eles estavam se adaptando à realidade do teletrabalho nas suas organizações e convivendo com situaçóes domésticas nunca antes experimentadas. Era uma mistura de ambiente profissional e pessoal, crianças que precisavam de atenção e cuidados, inseguranças, preocupaçóes e acúmulos de tarefas. Alguns eram médicos no front da batalha, outros estavam em comitês de crises das suas organizações e vários tinham filhos pequenos em casa.

Os coordenadores dos cursos executivossedesculparam pela ansiedade e pararam para ouvir os discentes. Por ser pequena e zelar pela excelência, a escola sempre teve como marca uma forte proximidade entre professores e alunos. Essa aproximaçáo foi retomada virtualmente em reunióes da diretora e da coordenaçáo dos MBAs com os alunos, que permitiram compreender a nova realidade que estes passavam. Cada turma pôde escolher a carga horária de aula com que conseguiria lidar naquele momento e toda a grade do curso foi revista para adaptação a essa disponibilidade. Aulas experimentais foram ofertadas para que os alunos conhecessem a proposta. Eles estavam inseguros, porque fazer um curso on-line não havia sido sua opção original, mas compreenderam a importância da virtualização. Tempos atípicos requeriam quebras de paradigma. Foi o que aconteceu. As aulas foram virtualizadas e ofertadas nos limites de capacidade das pessoas, sem o compromisso de que o calendário acadêmico se encerrasse no fim do ano, porque o foco precisava ser a qualidade. A escola assumiu ainda o compromisso de que, caso algumas aulas não fossem bem avaliadas pelo grupo por conta da plataforma on-line, estas seriam repostas presencialmente no futuro. $\mathrm{O}$ coordenador do curso se manteve presente em todos os encontros, para manter contato com a turma e ouvir feedbacks.

Após as aulas terem sido retomadas via Zoom, surgiram diversas matérias na imprensa questionando a segurança da plataforma. Alguns alunos chegaram a ter o sistema proibido nos computadores de suas empresas. Mais uma vez, a escola precisou aprender. Consultou especialistas em TI e o maior centro de segurança cibernética dos Estados Unidos (UTSA), e reconfigurou as opçóes de segurança e os procedimentos de entrada na sala de aula virtual. A taxa de evasão de alunos foi muito baixa e alguns poucos alunos pediram transferência para o segundo semestre, por questóes de conciliação com a atividade profissional, que passou a ser mais demandante.

\section{E O FUTURO?}

O professor Vijad Goviradajan, da Harvard Business School, afirmou em um webinar que $90 \%$ das universidades fechariam suas portas em 30 anos. A previsão inicial, de que a inteligência artificial diminuiria a busca pelo ensino superior e de que muitas universidades encerrariam atividades, fora antecipada em 20 anos. Nos encontros de associaçóes de escolas de negócio, Elaine já vinha escutando que muitas escolas deixariam de existir, principalmente as de marcas menos relevantes, mas um encolhimento tâo forte do mercado era assustador. Diversas perguntas começaram a fervilhar em sua mente: Como o setor seria afetado pela pandemia? Qual o movimento comercial das grandes escolas do exterior? Elas buscariam novos mercados para compensar perdas locais? Que desafios e oportunidades o Coppead teria para expansão geográfica, considerando sua marca local forte?

A transição do Coppead para o ambiente remoto síncrono se deu com naturalidade. Foi feita com menos planejamento do que o desejado, mas deu muita confiança para a equipe. $\mathrm{O}$ aprendizado dos professores e alunos sobre o uso das plataformas foi muito acelerado e manteve a escola alinhada ao processo de ensino e aprendizagem em que sempre acreditou, centrado no aluno. Elaine percebia que o Coppead tinha sido altamente responsivo no curto prazo, mas que seria importante olhar a estratégia de longo prazo. 
Era preciso solidificar os conhecimentos obtidos e a imagem inovadora da escola. Havia um mar de possibilidades também para a criação de novas parcerias. Mas essas oportunidades eram compatíveis com a realidade de uma escola de negócios pequena?

A escola permaneceria com suas aulas virtuais enquanto a pandemia durasse. Porém, o conhecimento adquirido, a experimentação do novo e as mudanças de comportamento das pessoas trouxeram novas oportunidades. Quais seriam as possibilidades? O que diferenciaria o Coppead neste novo mundo? Como a escola deveria rever seu portfólio para incorporar novos produtos, já que professores e alunos poderão estar em sala de aula presencialmente ou virtualmente? Que novas competências o mercado demandará depois da pandemia?
São muitas dúvidas, desafios e oportunidades. Elaine tinha uma única certeza: é na adversidade que se cresce. A pandemia poderia ser vista com desânimo, mas também como um convite à superaçáo. Pensando no Coppead, Elaine tinha uma certeza: a escola seguiria inovando.

\section{NOTAS}

1. Coordenadoria dos Programas de Pós-Graduação em Engenharia da UFRJ.

2. https://www.edx.org/ (recuperado em 26 de Junho, 2020)

3. https://www.beacademy.com.br/ (recuperado em 26 de Junho, 2020)

4. https://somostera.com (recuperado em 26 de Junho, 2020)

5. https://conteudo.hsm.com.br/hsm-university/

(recuperado em 26 de Junho, 2020) 
Notas de Ensino

\section{RESUMO}

Este caso de ensino descreve o processo de adaptação para a virtualização do ensino no Coppead, uma das principais escolas de pós-graduação em administração no Brasil. A mudança ocorre impulsionada pelo isolamento social adotado no país por conta da pandemia de COVID-19. O caso relata as decisóes que o colegiado de professores, liderado pela diretora Elaine Tavares, precisou tomar para contornar a quarentena e garantir a continuidade das aulas no Mestrado, Doutorado e MBA Executivo. Os desafios dessa transição são discutidos, porém mais importante que isso são as oportunidades estratégicas que essa experiência abre para a inovação da escola nos anos futuros.

Palavras-chave: caso de ensino; inovação; ensino remoto; educação.

\section{FONTES DOS DADOS}

As informaçốes contidas neste caso são oriundas de observaçóes e entrevistas realizadas com docentes e funcionários do Coppead. Também foram utilizadas fontes públicas, tais como site oficial e sites especializados em negócios. Os dados foram coletados de abril a maio de 2020. A estrutura do caso e das notas de ensino seguiu as recomendaçóes de Chimenti (2020), Alberton e Silva (2018) e Roesch (2006).

\section{OBJETIVOS DE APRENDIZAGEM}

O caso foi elaborado para aplicaçáo com alunos de pós-graduação (Mestrado ou Especialização) em disciplinas de Estratégia e Inovaçáo. $\mathrm{O}$ caso pode ser discutido com base na literatura de ecossistemas, cenários e inovação. Os alunos devem discutir estratégias e açóes para o Coppead entrar no ambiente virtual, debatendo o quanto essa mudança

\section{ABSTRACT}

This teaching case describes the process experienced by Coppead, one of the main graduate schools in business in Brazil, to adapt to e-learning. The change is driven by the social isolation adopted in the country due to the COVID-19 pandemic. The case reports on the decisions that the faculty collegiate, led by the director Elaine Tavares, has needed to take to circumvent the quarantine and ensure teaching continuity at Master, Doctoral, and Executive MBA levels. The case discusses the main challenges during the transition, but most importantly highlights the strategic opportunities that this shift has offered for innovation in the coming years.

Keywords: case study; innovation; e-learning; education.

impacta o futuro da escola. Também pode ser aplicado em cursos sobre gestão de educação e práticas ativas de ensino.

A utilização de casos de ensino tem como objetivo desenvolver nos participantes a capacidade analítica, de argumentaçáo e de tomada de decisão (Mauffette-Leenders, Erskine, \& Leenders, 1997), possibilitando o envolvimento ativo do aluno no processo de ensino-aprendizagem. Este caso tem os seguintes objetivos educacionais específicos:

(a) Entender como o setor tradicional de educação em particular está enfrentando uma transição para o mundo digital.

(b) Discutir como efeitos externos podem impulsionar a inovação, derrubando tradicionais barreiras à adoção e modificando a percepção de risco.

(c) Explorar o impacto das inovaçóes em ecossistemas de negócios, abordando os desafios das incumbentes.

(d) Utilizar análise de cenários para planejar estrategicamente o futuro de uma organizaçáo. 


\section{QUESTÕES PARA DISCUSSÃO}

Tendo em vista os objetivos acadêmicos propostos para o caso, sugerimos as questóes para discussão:

- Quais os principais desafios enfrentados pelo Coppead na transição para o ensino remoto?

- Como a pandemia impacta a adoção do ensino remoto no ecossistema da educação?

- A adoção das novas tecnologias digitais parece ser uma boa estratégia para qualquer escola de negócios?

- Como o Coppead deve desenhar sua atuação póspandemia, aproveitando a experiência obtida com a digitalização da sua sala de aula e mantendo a aprendizagem centrada no aluno?

\section{PLANO PARA APLICAÇÃO DO CASO}

Para aplicação do caso em sala de aula é fundamental que os alunos tenham sido orientados sobre o método e suas etapas, e sobre a importância do comprometimento de todos para criar um ambiente favorável à discussão e ao desenvolvimento de argumentos (Mauffette-Leenders et al., 1997). O professor deve estimular os alunos a se colocarem no lugar da protagonista da história, a diretora do Coppead Elaine Tavares, e a buscar compreender seus dilemas e as questôes envolvidas na decisão a ser tomada. Também é fundamental a leitura prévia da bibliografia recomendada (presente nas Referências).

Seguindo a estrutura do método do caso, recomenda-se o cumprimento de três estágios: (a) leitura e análise individual do caso, complementada pelas leituras recomendadas; (b) discussão do caso em pequenos grupos; e (c) discussão em plenária, mediada pelo professor, envolvendo todos os alunos. Sugere-se que a discussáo do caso em plenária tenha a duração de 90 minutos, assim distribuídos:

- 10 min: Abertura e visão geral da situação.

- 20 min: Análise do Coppead e desafios do ensino remoto.

- 20 min: Ecossistema de Educação.

- 25 min: Transição para o digital e futuro da educação.

- 15 min: Fechamento com recomendaçóes.

\section{ABERTURA DA DISCUSSÃO PLENÁRIA DOS CASOS}

O professor poderia iniciar a discussão em plenária perguntando aos alunos qual o principal dilema enfrentado pela diretora do Coppead, o que permitirá a ele alinhar o dilema antes da discussão nas salinhas. Enquanto alguns alunos tratarão objetivamente o dilema apresentado (como e se o Coppead deve ingressar no ensino remoto), alguns poderão trazer questôes mais amplas, como o futuro das organizaçóes de ensino em geral, dado o advento de inovações disruptivas na educação.

\section{1) Desafios do ensino remoto para o Coppead}

Após a discussão nos pequenos grupos, o professor pode iniciar a discussão perguntando se a pandemia é uma ameaça ou oportunidade para o Coppead. Os alunos podem ser estimulados a escolher uma das opçóes, como numa enquete, e alguns devem ser escolhidos para justificar suas escolhas. O debate tende a ser acirrado, uma vez que os alunos podem considerar que a pandemia é uma grave ameaça, levando em conta a potencial diminuição de alunos e de receita, e a ameaça de novos entrantes. Por outro lado, alguns podem argumentar que a pandemia traz oportunidades, pois as barreiras à inovação tradicionalmente presentes em incumbentes caem, abrindo espaço para inovação. Os conceitos explorados por Day e Schoemaker (2000) sobre as armadilhas das incumbentes e de Christensen (1997) sobre o dilema do inovador podem ser explorados, provocando uma reflexáo sobre o quanto o ensino remoto é uma inovação incremental ou disruptiva.

Uma análise cuidadosa mostrará que o e-learning tem um conjunto de tecnologias emergentes pelo seu potencial de criar novos mercados e novos modelos de negócio. Também pode ser considerado disruptivo pelo potencial de entregar uma experiência melhor (em termos de personalização do ensino e de conveniência) a um custo relativamente menor (devido à escalabilidade das soluçóes existentes).

Nesse momento, o professor pode sugerir aos alunos refletir sobre a realidade do Coppead, o que deixará claro que vários desses custos não deixam de existir, já que a escola provavelmente não abriria mão de suas instalaçôes e que boa parte da estrutura de custos é fixa.

Além desse aspecto, o professor pode perguntar aos alunos quem seriam os impulsionadores e gatekeepers da inovação, e quais seriam as suas razóes, provocando uma reflexão sobre as barreiras levantadas por diversos stakeholders do ecossistema de educação, como os próprios professores, os reguladores no governo e na própria UFRJ, além de alunos e da sociedade em geral. A Figura 2 apresenta a modelagem de Rodrigues, Chimenti e Nogueira (2021) sobre os fatores que impulsionam ou previnem a adoção de e-learning. 


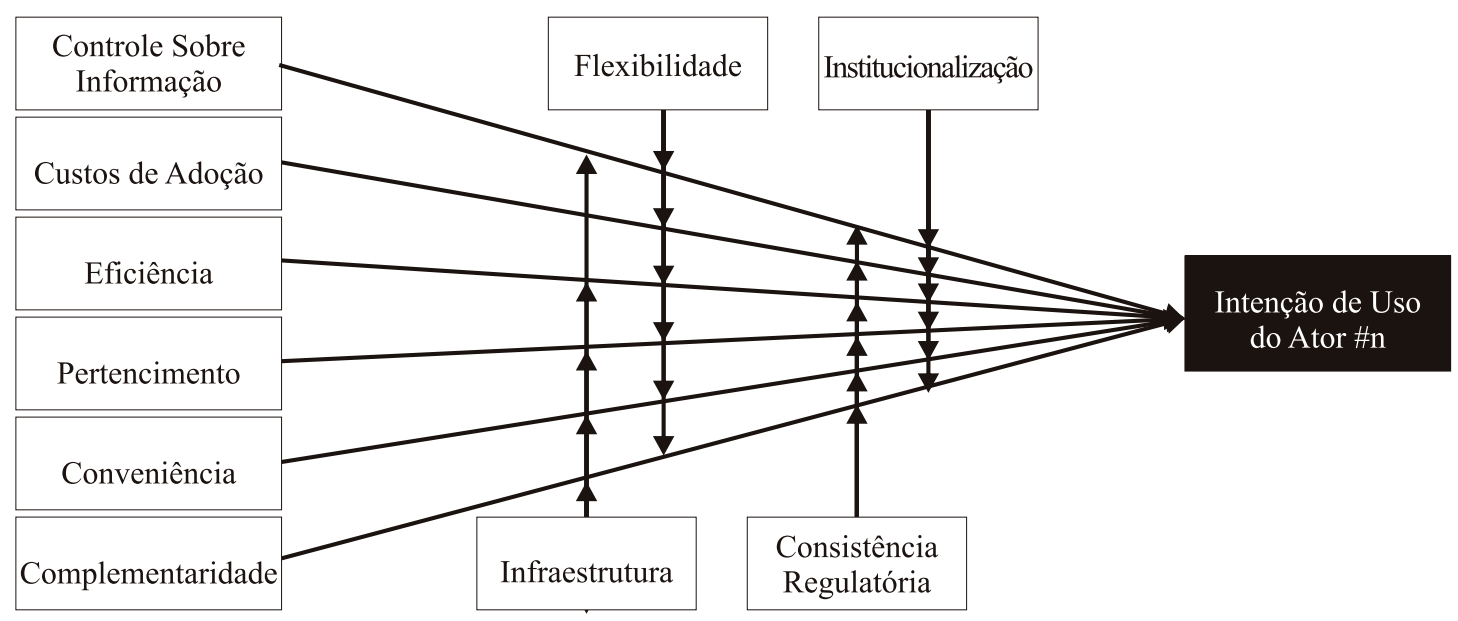

Figura 2. Fatores para adoção de e-learning.

Fonte: Adaptado de Rodrigues, M. A., Chimenti, P., \& Nogueira, A. R. R. (2021). An exploration of eLearning adoption in the educational ecosystem. Education and Information Technologies, 26, 585-615. https://doi.org/10.1007/s10639-020-10276-3

\section{2) Ecossistema da educação}

Outra contribuição de Rodrigues et al. (2021) para a discussão sobre adoção do e-learning diz respeito à percepção de que não se trata de apenas um ator, mas de uma adoção em múltiplos níveis, por múltiplos stakeholders.

O professor pode introduzir essa discussão perguntando para a turma quem decide adotar o e-learning. Com a emergência de diversos atores na discussão, o conceito de ecossistema de negócios pode ser introduzido, apontando a relevância da compreensão ampla do ecossistema no qual uma organização está inserida para a elaboração de sua estratégia.

A partir dessa constatação, o professor pode construir, junto com os alunos, o ecossistema de educação (vide Figura 3 para uma sugestão de desenho de ecossistema), estimulando os participantes a refletirem sobre quais organizaçóes e indivíduos fazem parte dele e quais as conexóes existentes (e ausentes) entre esses elementos.

A análise do ecossistema em sala de aula pode mostrar a entrada de novos atores no setor de educaçáo, reforçando como as barreiras da indústria se diluíram, trazendo para o jogo novos participantes de grande peso, como Google, por exemplo, que tem poder para mudar diversas regras. Também ajuda a identificar potenciais parceiros para escolas tradicionais como o Coppead nessa entrada no mundo virtual, como desenvolvedores de plataformas, desenvolvedores de games, entre outros.

\section{3) Cenários para o futuro da educação}

A partir do desenho do ecossistema, o professor pode provocar os alunos a pensarem no futuro da educaçáo, utilizando cenários. A leitura prévia de Garvin e Levesque (2005) ou Schoemaker (1995) pode auxiliar essa discussão.

O planejamento com cenários envolve vários elementos que juntos formam uma visão multifacetada do futuro. Ao invés de apontar um único caminho, a ideia é trabalhar com múltiplos futuros, dando conta das possibilidades estratégicas que se abrem no setor, e preparando a organização para múltiplas possibilidades de futuro. $\mathrm{O}$ processo se inicia com a definição do escopo geográfico e horizonte de tempo, aqui definidos como Brasil, daqui a 10 anos. A partir dessa definição, são levantadas as principais forças de mudança, que são então combinadas nos cenários futuros. As forças de mudança podem ser categorizadas como predeterminadas ou incertas, sendo as primeiras denominadas 'tendências' e a segundas, 'incertezas'.

As principais tendências para o ecossistema da educação podem ser identificadas pelos alunos a partir de suas experiências e da leitura do caso, tais como: inclusáo digital, mobilidade, queda das barreiras geográficas, abundância de ofertas, entre outras. 


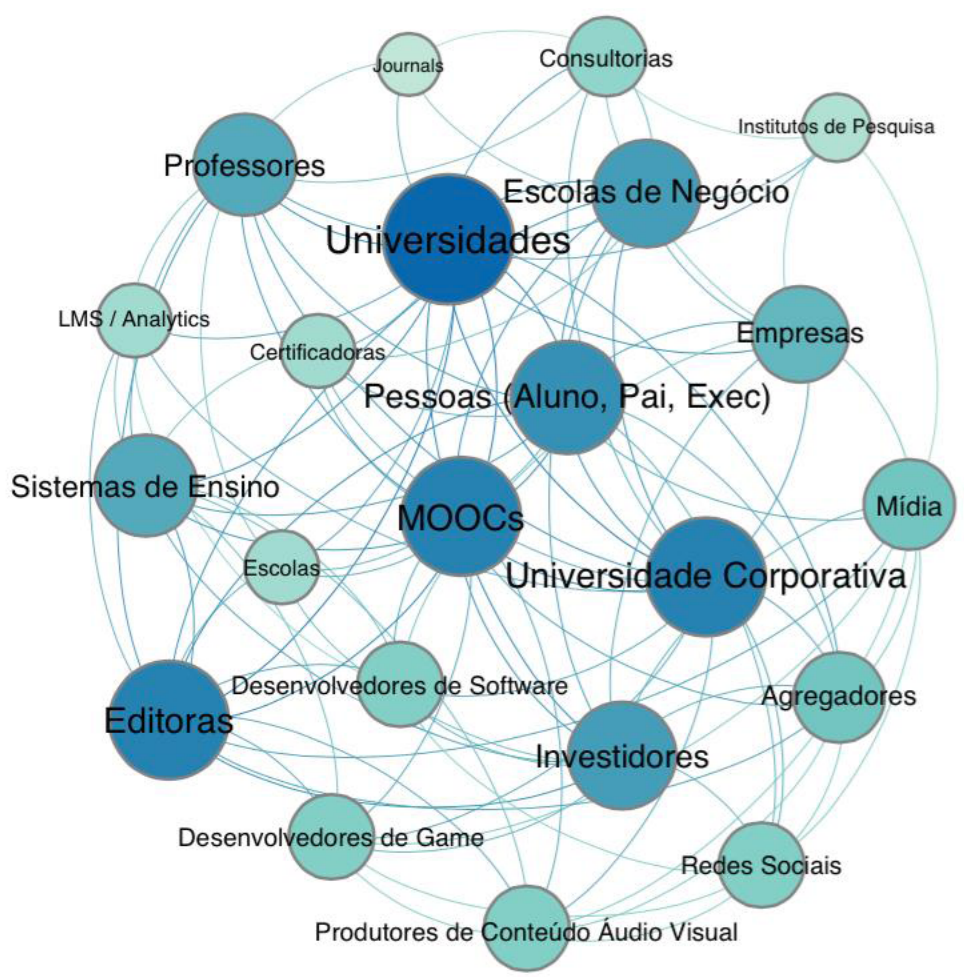

Figura 3. Ecossistema da educação.

Fonte: Chimenti, P. C. P. S., Rodrigues, M. A. S., \& Nogueira, A. R. R. (2015, June). O futuro da educaçấo: Uma análise de cenários. Anais do Encontro de Estudos em Estratégia - 3Es, Brasília, Brazil, 7.

Uma vez que esses fatores predeterminados foram identificados, as outras forças de mudança, sobre as quais se têm dúvidas, são classificadas como incertezas. É importante destacar que, para os acadêmicos que trabalham com a metodologia de planejamento com cenários, as incertezas são o 'pulo do gato', que de fato trazem diferencial ao planejamento (Schoemaker, 1995; Garvin \& Levesque, 2005). Isso porque, embora a maioria das empresas planeje olhando apenas as tendências, são as incertezas que permitem uma visão de fato estratégica, que considera possibilidades de futuro que poderiam ser ignoradas pela organização. Sendo assim, sua análise auxilia as empresas a observarem fenômenos que não estavam em seu radar, a lidar com o desconhecido e a identificar oportunidades nas mudanças. Isso, é claro, sem ter a intenção de antever todas as incertezas.

É importante destacar que o professor e os alunos devem ter liberdade para escolher as incertezas para o ecossistema descrito, sendo essa análise estratégica um exercício criativo, sem respostas certas ou erradas. Os cenários apresentados nesta nota de ensino não têm como objetivo prescrever uma resposta certa, mas auxiliar o docente com subsídios para esse exercício de criatividade com a turma. Os cenários a seguir vêm da pesquisa de Chimenti, Rodrigues e Nogueira (2015), que mapeou as seguintes incertezas:
Massificação x Customização: Dicotomia entre o ensino virtual personalizado e o ensino presencial massificado. As plataformas on-line permitem um alcance bem maior que a sala de aula tradicional, proporcionando ensino às pessoas que por questóes geográficas, de rotina ou de renda não tinham antes acesso à educação universitária. Outro ponto é uma mudança gradual na percepção de alunos e de empresas sobre a qualidade do ensino a distância. Os alunos podem discutir como a pandemia do COVID-19 e a quarentena empurraram todo o ecossistema de educaçáo para uma virtualizaçáo muito mais acelerada. Entretanto, a intensidade de uso e os modelos de e-learning que serão adotados no futuro ainda parecem incertos.

Certificação pelo Mercado x Diploma: A segunda incerteza mapeada na pesquisa trata da possibilidade de, no futuro, a graduação ser substituída por uma certificação que ateste os conhecimentos de uma pessoa, independentemente da forma como tais conhecimentos foram adquiridos. Assim, o formato tradicional da graduação com um diploma ao final seria substituído por testes certificadores (como os feitos pelos advogados - OAB). Num futuro possível em que o formato atual das graduaçóes será coisa do passado, cada estudante construirá seu track de ensino pessoal e o mercado exigirá apenas uma comprovação dos conhecimentos e 
competências, sem uma preocupaçáo com o processo. Essa possibilidade é impulsionada pela dependência cada vez menor que os alunos têm dos professores como fonte de saber. Os entrevistados destacam de forma unânime a dificuldade em prender a atençáo dos alunos e ensinar utilizando métodos tradicionais. Nesse sentido, o diploma tende a ser desvalorizado no médio prazo, sendo substituído por novas metodologias de aprendizado.

De acordo com o método de cenários, cada incerteza crítica é reduzida a um único continuum ou eixo, com as possibilidades extremas colocadas de modo diametralmente oposto. Os dois eixos são consequentemente combinados para criar uma matriz $2 \times 2$, com quatro diferentes quadrantes representando futuros a serem explorados. O objetivo é terminar com poucos 'futuros' altamente contrastantes entre si. Os futuros que resultaram da interação das incertezas críticas são chamados cenários. Eles são hipóteses plausíveis e alternativas acerca de como pode vir a ser o mundo, desenhados especialmente para realçar riscos e oportunidades para a organização. Cenários desafiam os participantes a pensar, incitando uma apreciação mais profunda de vários fatores que podem moldar o futuro. Não existem cenários certos ou errados.

A combinação das incertezas descritas anteriormente deu origem aos cenários apresentados na Figura 4, em que estão presentes as tendências identificadas.

Cada cenário é nomeado de forma a ser facilmente identificado pelos participantes do processo de planejamento e usualmente escolhem-se nomes simples, associados ao seu significado - nesse caso foram utilizados nomes de conhecidos filmes. Do mesmo modo, foram produzidas descriçôes que resumem as principais características de cada um deles. De acordo com o método, não são associadas probabilidades aos cenários. $\mathrm{O}$ objetivo não é tentar prever um futuro, mas preparar a organização para cada um deles.

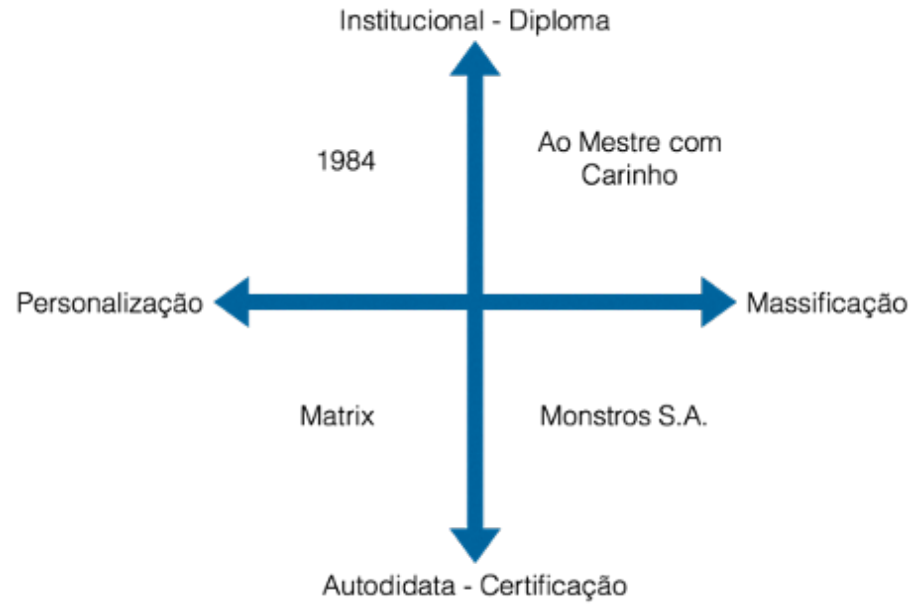

Figura 4. Cenários para o futuro da educação.
A seguir, são apresentadas as narrativas para cada um dos quatro cenários.

Cenário 1: Ao Mestre com Carinho. Esse é o cenário mais próximo da prática atual no setor. Nele, o diploma continua valorizado e as aulas permanecem ocorrendo predominantemente no modelo sala de aula física, expositiva, padronizada e massificada. Entretanto, por conta dos avanços em inclusão digital e mobilidade, a atençâo dos alunos é cada vez mais concorrida e novas tecnologias são incorporadas como complementos ao ensino em aula.

Cenário 2: Monstros S.A.: Nesse cenário, a sala de aula continua importante e o ensino permanece pouco customizado, sendo distribuído de forma massificada para muitos alunos. Entretanto, o desgaste do modelo universitário tradicional acarreta o crescimento de entidades certificadoras, que passam a atestar para o mercado que determinado candidato domina os requisitos técnicos e as competências necessárias ao desempenho de uma função. No limite, as próprias empresas realizariam essa avaliação.

Cenário 3: Matrix. Em oposição ao Cenário 1, esse é, sem dúvida, o mais disruptivo para as instituiçôes que hoje lideram o setor. Nesse futuro, acelerado pela pandemia, a principal plataforma de aprendizado é on-line, e a sala de aula física é considerada algo ultrapassado. A tecnologia permite que alunos assistam aulas, debatam entre si e interajam com professores de suas casas, como se estivessem no mesmo ambiente. Cada aluno cria para si, com a ajuda da plataforma, um conjunto de disciplinas totalmente customizado, juntando os conhecimentos de que necessita para seu futuro profissional. Os conteúdos são entregues da forma que o aluno escolher, audiovisual, texto, áudio puro, etc. As universidades tradicionais foram substituídas por entidades certificadoras que atestam para cada tipo de empregador as competências dos seus candidatos. $\mathrm{O}$ importante para o mercado é o que você sabe, não como aprendeu.

Cenário 4: 1984. Nesse cenário, muitas universidades migraram para o on-line, adequando suas ofertas e mantendo sua relevância no ecossistema. Parcerias das universidades físicas com os MOOCs permitem uma ampliação das ofertas e um conjunto de disciplinas mais flexível. O ensino se dá de forma mais personalizada, ajustando a entrega de conteúdos às necessidades dos alunos. O diploma universitário permanece importante, com a criação de uma gama de possibilidades maior e mais acessibilidade em relação a preço e alcance geográfico.

Apesar de os cenários dificilmente se concretizarem em seus formatos extremos, são úteis para organizaçóes que atuam no ecossistema e pretendem manter sua relevância no futuro. A ideia é que, circunscrevendo as possibilidades futuras, a organização se prepare para o que possa 
ocorrer - qualquer um dos quatro cenários identificados. Para ser relevante em cada um deles, será necessário o desenvolvimento ou a aquisição de competências e recursos que podem hoje não existir na organização. Uma virtude do método é indicar antecipadamente açóes a serem tomadas para que sua universidade esteja adequadamente posicionada em cada um dos quatro futuros. Preparar-se não implica a imediata realização de investimentos, mas a identificação de parceiros e fornecedores com os quais podem ser celebrados contratos futuros (se possível, exclusivos), com vigência adequada ao horizonte de tempo do planejamento. Essa abordagem é a de opçóes reais, comum em projetos de grande valor e componentes de incerteza, tais como os de petróleo e energia (Day \& Schoemaker, 2000).

\section{4) $\bigcirc$ que fazer?}

Nesse momento da discussão, o professor deve sair do foco macro (ecossistema) para voltar ao Coppead e à protagonista do caso. A partir dos cenários desenhados, como Elaine Tavares pode preparar a escola para o futuro? É importante relembrar aos alunos que o objetivo desse exercício não é escolher um futuro, mas preparar-se para todos.

Essa estratégia começa com a avaliação dos 'fatores críticos de sucesso' para cada cenário. Os alunos vão identificar rapidamente qual o cenário mais fácil (Ao Mestre com Carinho) e qual o mais desafiador (Matrix) para a escola. Dadas as restriçóes de tempo de uma aula, recomenda-se trabalhar os fatores críticos desses dois cenários extremos, enfatizando com a turma suas semelhanças e, principalmente, suas diferenças.

No cenário Ao Mestre com Carinho, os alunos perceberão que a maioria dos fatores críticos de sucesso, como reputação, corpo docente altamente qualificado, ótimos alunos, entre outros, já é dominada pelo Coppead. Por outro lado, o cenário Matrix pode demandar características bem distintas, como uma plataforma digital interativa, domínio de competências de criação de conteúdo audiovisual, uma comunicação mais abrangente para criação de uma marca global (já que a competição passa a ser global), escalabilidade dos serviços e uma interação com alunos muito mais parecida com um coaching do que com uma aula tradicional.

Nesse cenário, o Coppead (como todas as instituições de ensino tradicionais) precisa se reinventar e a entrada 'forçada' no ambiente digital parece um resultado positivo da pandemia, já que faz a escola caminhar e evoluir no desenvolvimento de novas competências.

\section{FECHAMENTO DO CASO}

O professor pode concluir a discussão trazendo os desdobramentos da entrada no ambiente virtual do Coppead, descritos a seguir, e reforçando a máxima 'crises são oportunidades'. Cabe destacar que as escolhas estratégicas futuras da escola influenciarão fortemente sua capacidade de responder aos desafios futuros, por meio da construçáo das competências necessárias no futuro ecossistema da educação.

\section{NÍVEL DE DIFICULDADE DO CASO}

O nível de dificuldade do caso foi definido a partir da proposta de Erskine, Leenders e Mauffette-Leenders (1998). Segundo os autores, os casos apresentam graus diferentes de dificuldade em três dimensôes: analítica, conceitual e de apresentação. Cada uma delas se subdivide em três níveis de dificuldade, formando o chamado 'cubo de dificuldade do caso'. A dimensão analítica diz respeito à natureza da tarefa do estudante ao se deparar com o dilema do caso, a dimensão conceitual refere-se à complexidade dos conceitos envolvidos e a dimensão de apresentação abrange a quantidade e qualidade da informaçáo que está contida no caso. A classificação do presente caso é apresentada na Tabela 1 .

Tabela 1. Nível de dificuldade do caso.

\begin{tabular}{lcl}
\hline Dimensão & $\begin{array}{c}\text { Nível de } \\
\text { dificuldade }\end{array}$ & Razóes \\
\hline Analítica & 2 & $\begin{array}{l}\text { O caso apresenta o dilema de digitalização das aulas do Coppead em meio à pandemia. Ao aluno cabe, com base } \\
\text { no dilema, analisar as informaços trazidas no caso e propor soluçóes bem fundamentadas. }\end{array}$ \\
$\begin{array}{l}\text { Conceitual } \\
\text { De apresentação }\end{array}$ & 3 & A análise do caso envolve a articulação de diferentes conceitos, tais como inovação, ecossistemas e cenários. \\
\hline
\end{tabular}

Nota. Elaborado a partir de Erskine, J. A., Leenders, M. R., \& Mauffette-Leenders, L. (1998). Teaching with cases. London: School of Business Administration, The University of Western Ontario. 


\section{REFERÊNCIAS}

Alberton, A., \& Silva, A. B. (2018). Como escrever um bom caso para ensino? Reflexóes sobre o método. Revista de Administração Contemporânea, 22(5), 745-761. https://doi.org/10.1590/1982-7849rac2018180212

At Harvard's new 'virtual classroom,' students tune in to class from computers anywhere. (2015). Fox Business. Retrieved from https://www.foxbusiness.com/features/at-harvardsnew-virtual-classroom-students-tune-in-to-class-fromcomputers-anywhere

Chimenti, P. C. P. S., Rodrigues, M. A. S., \& Nogueira, A. R. R. (2015, June). O futuro da educação: Uma análise de cenários. Anais do Encontro de Estudos em Estratégia - 3Es, Brasília, Brazil, 7.

Chimenti, P. C. P. de S. (2020). Reflexões sobre Casos de Ensino Memoráveis. Revista de Administraçâo Contemporânea, 24(5), 376-379. https://doi.org/10.1590/1982-7849rac2020200102

Christensen, C. M. (1997). The Innovator's Dilemma: When new technologies cause great firms to fail. Boston, Massachusetts: Harvard Business Review Press.

Day, G., \& Schoemaker, P. (2000). A different game. In G. S. Day, P. J. H. Schoemaker, \& R. E. Gunther (Eds.), Wharton on managing emerging technologies (Chap. 1). New York: Wiley.

Erskine, J. A., Leenders, M. R., \& Mauffette-Leenders, L. (1998). Teaching with cases. London: School of Business Administration, The University of Western Ontario.
Garvin, D. A., \& Levesque, L. C. (2005, November). A Note on Scenario Planning. Harvard Business School Background Note 306-003, November 2005. Retrieved from https://www.hbs.edu/faculty/Pages/item.aspx?num=32841

Mauffette-Leenders, L. A., Erskine, J. A., \& Leenders, M. R. (1997). Learning with Cases. Ontario: University of Western Ontario.

Rodrigues, M. A., Chimenti, P., \& Nogueira, A. R. R. (2021). An exploration of eLearning adoption in the educational ecosystem. Education and Information Technologies, 26, 585-615. https://doi.org/10.1007/s10639-020-10276-3

Roesch, S. M. A. (2006, September). Notas sobre a construção de casos para ensino. Encontro Nacional da Anpad, 2006, Salvador, 30. Retrieved from http://www. anpad.org.br/eventos.php?cod evento $=1 \& \operatorname{cod}$ edicao $\underline{\text { subsecao }=149 \& \operatorname{cod} \text { evento edicao }=10 \& \operatorname{cod} \text { edicao }}$ trabalho $=5497$

Schoemaker, P. J. H. (1995). Scenario planning: A tool for strategic thinking. Sloan Management Review, 36(2), 25-40. Retrieved from https://www.researchgate.net/ publication/220042263 Scenario Planning A Tool for Strategic Thinking

Yang, G. (2019). Is it time to retire the Harvard Case Study? Retrieved from https://poetsandquants.com/2019/10/05/ is-it-time-to-retire-the-harvard-case-study/ 


\section{Autoria}

\section{Roberta Dias Campos}

Universidade Federal do Rio de Janeiro, Instituto COPPEAD de Administração

Rua Pascoal Lemme, no 355, Cidade Universitária, 21941-918, Rio de Janeiro, RJ, Brasil.

E-mail: roberta.campos@coppead.ufrj.br

(D) https://orcid.org/0000-0002-7091-7901

\section{Elaine Tavares}

Universidade Federal do Rio de Janeiro, Instituto COPPEAD de Administração

Rua Pascoal Lemme, no 355, Cidade Universitária, 21941-918, Rio de Janeiro, RJ, Brasil.

E-mail: elaine.tavares@coppead.ufrj.br

(D) https://orcid.org/0000-0002-1107-2101

\section{Paula Castro Pires de Souza Chimenti*}

Universidade Federal do Rio de Janeiro, Instituto COPPEAD de Administração

Rua Pascoal Lemme, no 355, Cidade Universitária, 21941-918, Rio de Janeiro, RJ, Brasil.

E-mail: paula.chimenti@coppead.ufrj.br

(D) https://orcid.org/0000-0002-6492-4072

\section{Leonardo Marques}

Universidade Federal do Rio de Janeiro, Instituto COPPEAD de Administração

Rua Pascoal Lemme, no 355, Cidade Universitária, 21941-918, Rio de Janeiro, RJ, Brasil.

E-mail: leo.marques@coppead.ufrj.br

(D) https://orcid.org/0000-0001-8960-8191

* Autora Correspondente

\section{Direitos Autorais}

A RAC detém os direitos autorais deste conteúdo.

\section{Financiamento}

Os autores relataram que não houve suporte financeiro para pesquisa deste artigo.

\section{Contribuiç̧ões dos Autores}

$1^{a}$ autora: conceitualização (igual); curadoria de dados (igual); redação - rascunho original (igual); redação - revisão e edição (igual); supervisão (igual); validaçáo (igual).

$2^{\text {a }}$ autora: conceitualização (igual); curadoria de dados (igual); redação - rascunho original (igual); redação - revisão e ediçâao (igual); supervisão (igual); validação (igual).

$3^{\text {a }}$ autora: conceitualização (igual); curadoria de dados (igual); redação - rascunho original (igual); redação - revisão e edição (igual); supervisão (igual); validação (igual).

$4^{\mathrm{o}}$ autor: conceitualização (igual); curadoria de dados (igual); redação - revisão e edição (igual); supervisão (igual); validação (igual).

\section{Conflito de Interesses}

Os autores informaram que não há conflito de interesses.

\section{Método de Revisão por Pares}

Este conteúdo foi avaliado utilizando o processo de revisão por pares duplo-cego (double-blind peer-review). A divulgaçáo das informaçôes dos pareceristas constantes na primeira página é feita somente após a conclusão do processo avaliativo, e com o consentimento voluntário dos respectivos pareceristas.

\section{Verificação de Plágio}

A RAC mantém a prática de submeter todos os documentos aprovados para publicação à verificação de plágio, mediante o emprego de ferramentas específicas, e.g.: iThenticate.

\section{Disponibilidade dos Dados}

A RAC incentiva o compartilhamento de dados mas, por observância a ditames éticos, não demanda a divulgação de qualquer meio de identificaçáo de sujeitos de pesquisa, preservando a privacidade dos sujeitos de pesquisa. A prática de open data é viabilizar a reproducibilidade de resultados, e assegurar a irrestrita transparência dos resultados da pesquisa publicada, sem que seja demandada a identidade de sujeitos de pesquisa. 